\title{
Hyperacute Allograft Rejection
}

National Cancer Institute

\section{Source}

National Cancer Institute. Hyperacute Allograft Rejection. NCI Thesaurus. Code C114848.

An immediate rejection of transplanted tissue caused by the presence of preformed antibodies to donor human leukocyte antigens. 